\title{
Anticancer effects of a specific mixture of nutrients in the multidrug-resistant human uterine sarcoma MES-SA/Dx5 and the drug-sensitive MES-SA cell lines
}

\author{
M.W. ROOMI, T. KALINOVSKY, N.W. ROOMI, M. RATH and A. NIEDZWIECKI \\ Dr Rath Research Institute, 1260 Memorex Drive, Santa Clara, CA 95050, USA
}

Received July 22, 2011; Accepted August 26, 2011

DOI: $10.3892 / o r .2011 .1471$

\begin{abstract}
A specific nutrient mixture (NM) containing lysine, proline, ascorbic acid and green tea extract has demonstrated a broad spectrum of antitumor activity against a number of cancer cell lines. In this study, our main objective was to investigate the comparative effects of NM on anticancer parameters, such as cytotoxicity, matrix metalloproteinase (MMP) secretion and Matrigel invasion in the human uterine sarcoma drug-resistant MES-SA/Dx5 and the drug-sensitive MES-SA cell lines. In addition we studied the effects of NM on P-glycoprotein (Pgp) on these cell lines. Cell proliferation was evaluated by MTT assay, MMPs by gelatinase zymography, invasion through Matrigel, morphology by H\&E and Pgp expression by Western blot analysis and immunodetection using FITC-conjugated antibody and rhodamine 123 (Rh123) accumulation and efflux assays. NM exhibited antiproliferative effects on MES-SA/ Dx 5 , by $20 \%$ at 50 and $100 \mu \mathrm{g} / \mathrm{ml}$ and by 36,40 and $48 \%$ at 250,500 and $1,000 \mu \mathrm{g} / \mathrm{ml}$, respectively. By contrast, $\mathrm{NM}$ treatment of MES-SA cells resulted in significantly increased cytotoxicity: 40, 46, 65 and $72 \%$ at 50,100, 500 and 1,000 $\mu \mathrm{g} /$ $\mathrm{ml}$, respectively. In both cell lines, zymography demonstrated a band corresponding to MMP-2 in normal cells and MMP-9 with phorbol 12-myristate 13-acetate treatment. The two MMPs showed dose-response inhibition by NM. As shown by Western blot analysis and immunodetection, NM treatment resulted in a dose-dependent decrease in Pgp expression in the MES-SA/Dx 5 cell line. The MES-SA cell line does not exhibit Pgp. NM enhanced the accumulation and efflux of the Pgp substrate, Rh123, in the MES-SA/Dx5 uterine sarcoma cell line but not in the drug-sensitive cell line, MES-SA. Therefore, it can be concluded that NM demonstrates potent anticancer effects in both the drug-resistant and sensitive cell lines and
\end{abstract}

Correspondence to: Dr Aleksandra Niedzwiecki, Dr Rath Research Institute, 1260 Memorex Drive, Santa Clara, CA 95050, USA E-mail: author@drrath.com

Key words: nutrients, multidrug resistant uterine sarcoma, MES-SA, MES-SA/Dx5, p-glycoprotein, matrix metalloproteinases, cytotoxicity, Matrigel invasion modulates Pgp, suggesting its potential therapeutic effects in drug-resistant as well as sensitive cancers.

\section{Introduction}

Certain cancer cells develop resistance to therapeutic agents as well as to a broad spectrum of unrelated compounds, and may develop a multidrug-resistant (MDR) phenotype (1-4). MDR is mediated by overexpression of the drug export protein, known as plasma membrane P-glycoprotein (Pgp), which increases transport of the therapeutic agents from the cells, resulting in decreased cellular accumulation of the agents and, thus, reduced therapeutic efficacy (5). Pgp has a molecular mass of approximately $150-170 \mathrm{kDa}$ and is a member of the ATP-binding cassette (ABC) transporters, encoded by the MDRl gene in humans (6-8). A number of human tissues normally express Pgp: Cancer cells, lymphocytes, renal, hepatic and testicular cells, intestinal epithelia and the endothelium at the blood-brain barrier. Numerous classes of anticancer drugs are affected by Pgp-mediated resistance. These drugs include anthracyclines, epipodophyllotoxins, inca alkaloids and microtubule drugs (9). In recent decades, significant efforts have been focused on reversing MDR by targeting Pgp. MDR-reversal agents include calcium channel blockers, calmodulin antagonists, steroidal agents, protein kinase $\mathrm{C}$ inhibitors, immunosuppressive drugs, antibiotics and surfactants. However, many of these identified MDR-reversing drugs result in side-effects, such as cardiac toxicity, hypotension and congestive heart failure $(10,11)$.

The fluorescent dye rhodamine (Rh)123 has been used extensively as an index of Pgp-mediated transport in rodent and tissue culture models. Rh123 cell exclusion has been employed as a reliable analytical tool to identify potential multidrug resistance reversal agents for use in chemotherapy $(12,13)$. Although arguments have been made that Rh123 is transported by multidrug resistance-associated protein (MRP)1, Perloff et al reported that Rh123 transport was unaffected by the MRP1 inhibitors probenecid and indomethacin (14). Furthermore, the National Cancer Institute, in conducting a drug screen in 58 different cell lines, demonstrated a positive correlation between Rh123 transport and the expression of Pgp, but not that of MRP (15).

A specific micronutrient mixture (NM) has exhibited potent anticancer activity in vivo and in vitro in over 40 cancer cell 
lines (16). The anticancer effects of the NM include: Inhibition of metastasis, tumor growth, matrix metalloproteinase (MMP) secretion, invasion, angiogenesis and cell growth, as well as the induction of apoptosis (16). We are currently investigating whether NM is effective in drug-resistant cancers. We decided to study the effects of NM on the human drug-insensitive uterine sarcoma MES-SA/Dx 5 and the drug-sensitive MES-SA cell lines, as the uterine sarcoma human cell line, MES-SA/ Dx5, has been reported to overexpress the MDRI gene product Pgp (17). The main objective of this study was to evaluate the effects of NM on cell viability, morphology, MMP expression and Matrigel invasion using the human drug-insensitive uterine sarcoma MES-SA/Dx5 and the drug-sensitive MES-SA cell lines in light of the effects of NM on Pgp expression in these cell lines.

\section{Materials and methods}

Cancer cell lines and culture. The human drug-insensitive uterine sarcoma MES-SA/Dx5 and the drug-sensitive MES-SA cell lines, obtained from the American Type Culture Collection (ATCC; Rockville, MD, USA), were grown in RPMI-1460 medium, supplemented with $10 \%$ fetal bovine serum, penicillin $(100 \mathrm{U} / \mathrm{ml})$ and streptomycin $(100 \mathrm{mg} / \mathrm{ml})$ in 24-well tissue culture plates (Costar, Cambridge, MA, USA). Cells were incubated with $1 \mathrm{ml}$ of medium at $37^{\circ} \mathrm{C}$ in a tissue culture incubator equilibrated with $95 \%$ air and $5 \% \mathrm{CO}_{2}$. At near confluence, the cells were treated with the NM at 0 , $50,100,250,500$ and $1,000 \mu \mathrm{g} / \mathrm{ml}$, in triplicate at each dose. Phorbol 12-myristate 13-acetate (PMA), at a dose of $100 \mathrm{ng} / \mathrm{ml}$ was added to the cells to induce MMP-9 secretion. The plates were then returned to the incubator. The medium and serum used were obtained from ATCC, and antibiotics (penicillin and streptomycin) were from Gibco BRL (Long Island, NY, USA). EGCG and other chemicals were obtained from Sigma.

Composition of the NM. The NM was composed of the following, at the indicated doses: Vitamin $\mathrm{C}$ (as ascorbic acid and as $\mathrm{Mg}, \mathrm{Ca}$, and palmityol ascorbate) $700 \mathrm{mg}$, L-lysine $1,000 \mathrm{mg}$, L-proline $750 \mathrm{mg}$, L-arginine $500 \mathrm{mg}$, N-acetyl cysteine $200 \mathrm{mg}$, standardized green tea extract [derived from green tea leaves, obtained from US Pharma Lab; the certificate of analysis indicated the following characteristics: Total polyphenol $80 \%$, catechins $60 \%$, epigallocatechin gallate (EGCG) $35 \%$ and caffeine $1.0 \%] 1,000 \mathrm{mg}$, selenium $30 \mu \mathrm{g}$, copper $2 \mathrm{mg}$ and manganese $1 \mathrm{mg}$.

Cytotoxicity: MTT assay. Cell viability was evaluated by MTT assay, a colorimetric assay based on the ability of viable cells to reduce a soluble yellow tetrazolium salt [3-(4,5-dimethylthiazol-2-yl) 2,5-diphenyl tetrazolium bromide] (MTT) to a blue formazan crystal by mitochondrial succinate dehydrogenase activity of viable cells. This test is a good index of mitochondrial activity and, hence, of cell viability. After 24-h incubation, the cells were washed with phosphate-buffered saline (PBS) and $500 \mu 1$ of MTT (Sigma, M-2128) $0.5 \mathrm{mg} / \mathrm{ml}$ in medium were added to each well. After MTT addition, the plates were covered and returned to the $37^{\circ} \mathrm{C}$ incubator for $2 \mathrm{~h}$, the optimal time for formazan product formation. Following incubation, the supernatant was carefully removed from the

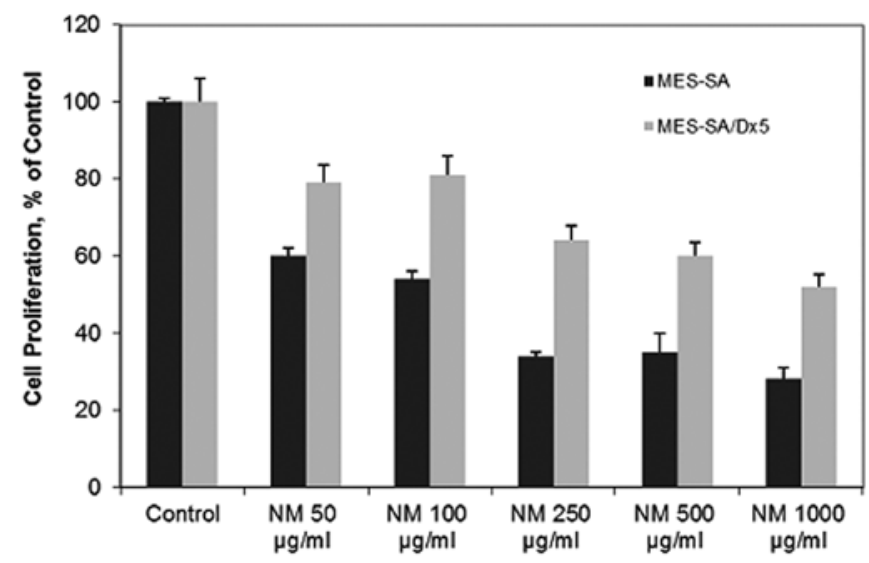

Figure 1. Effects of NM on MES-SA/Dx5 and MES-SA cells: MTT $24 \mathrm{~h}$.

wells, the formazan product was dissolved in $1 \mathrm{ml}$ DMSO and absorbance was measured at $570 \mathrm{~nm}$ in a BioSpec 1601, Shimadzu spectrometer. The $\mathrm{OD}_{570}$ of the DMSO solution in each well was considered to be proportional to the number of cells. The $\mathrm{OD}_{570}$ of the control (treatment without supplement) was considered $100 \%$.

Gelatinase zymography. MMP expression in conditioned medium was determined by gelatinase zymography. Gelatinase zymography was performed in $10 \%$ Novex Pre-Cast SDS polyacrylamide gel (Invitrogen Corporation) in the presence of $0.1 \%$ gelatin under non-reducing conditions. Culture medium $(20 \mu \mathrm{l})$ was mixed with sample buffer and loaded for sodium dodecyl sulphate (SDS)-polyacrylamide gel electrophoresis (PAGE) with tris glycine SDS buffer, according to the manufacturer's instructions (Novex). Samples were not boiled before electrophoresis. Following electrophoresis the gels were washed twice in $2.5 \%$ Triton X-100 for $30 \mathrm{~min}$ at room temperature to remove SDS. The gels were then incubated at $37^{\circ} \mathrm{C}$ overnight in substrate buffer containing $50 \mathrm{mM}$ Tris- $\mathrm{HCl}$ and $10 \mathrm{mM} \mathrm{CaCl}_{2}$ at $\mathrm{pH} 8.0$ and stained with $0.5 \%$ Coomassie Blue R250 in 50\% methanol and 10\% glacial acetic acid for $30 \mathrm{~min}$ and destained. Upon renaturation of the enzyme, the gelatinases digest the gelatin in the gel and give clear bands against an intensely stained background. Protein standards were run concurrently and approximate molecular weights were determined by plotting the relative mobilities of known proteins.

Matrigel invasion. Invasion studies were conducted using Matrigel (Becton-Dickinson) inserts in 24-well plates. Suspended in medium, cells were supplemented with nutrients, as specified in the design of the experiment and seeded on the insert in the well. Therefore, both the medium on the insert and in the well contained the same supplements. The plates with the inserts were then incubated in a culture incubator equilibrated with $95 \%$ air and $5 \% \mathrm{CO}_{2}$ for $24 \mathrm{~h}$. Subsequently, the media from the wells were withdrawn. The cells on the upper surface of the inserts were gently scrubbed away with cotton swabs. The cells that had penetrated the Matrigel membrane and migrated onto the lower surface of the Matrigel were stained with $\mathrm{H} \& \mathrm{E}$ and visually counted under the microscope. 

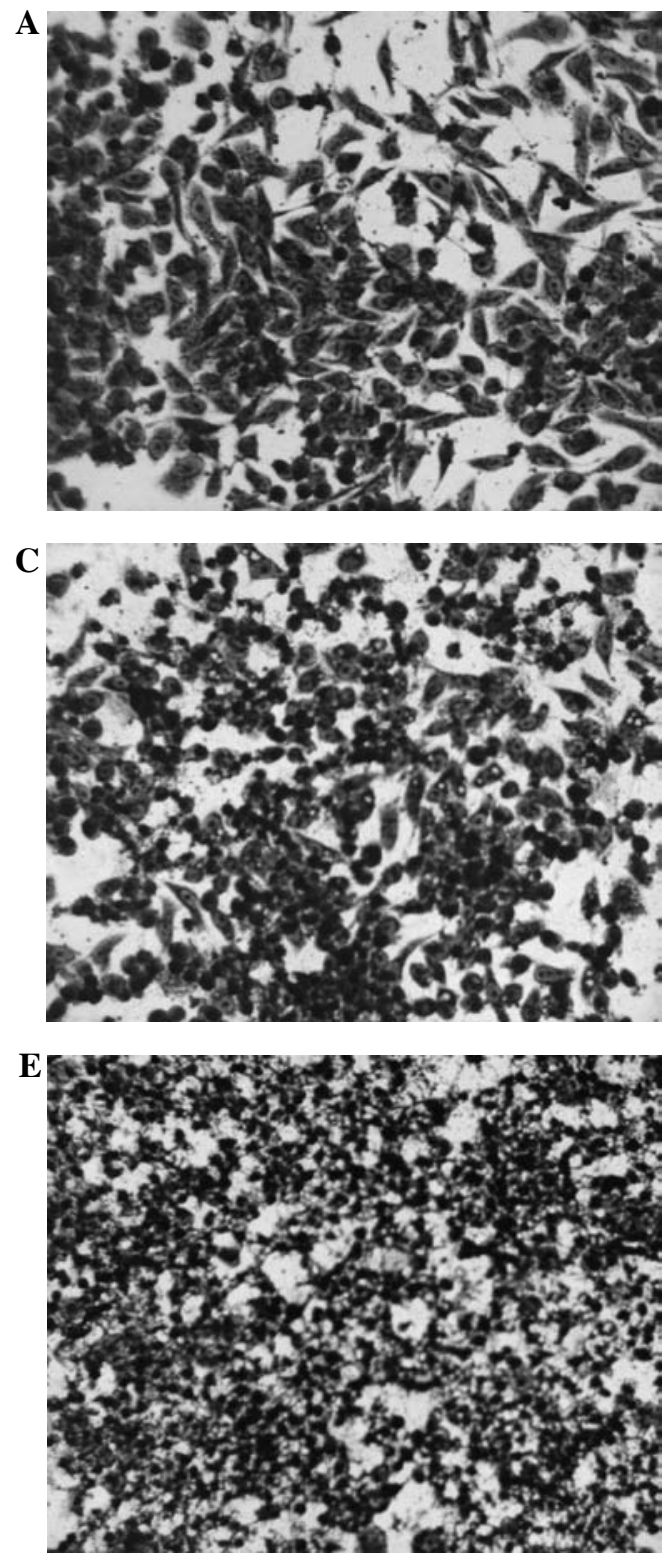
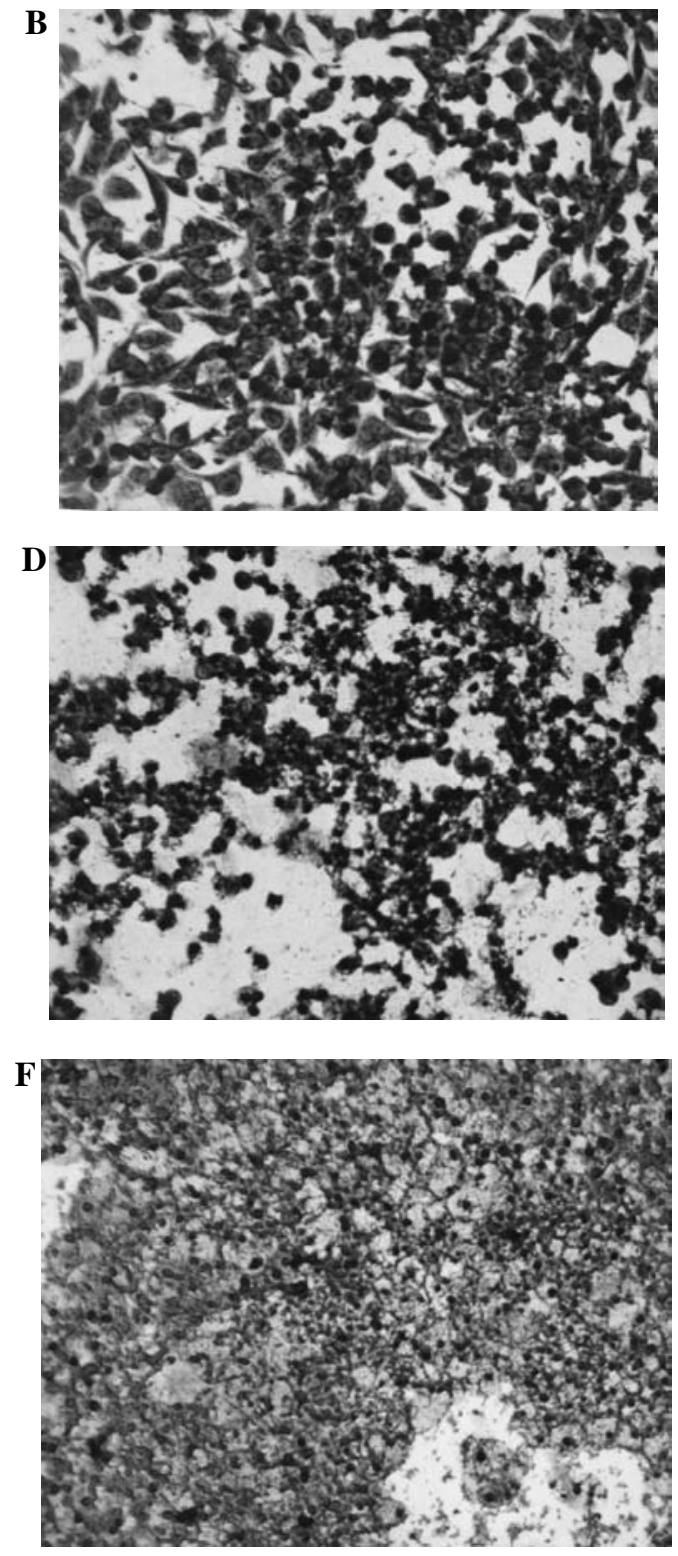

Figure 2. Effects of NM on morphology of MES-SA cells: H\&E staining. (A) Control, (B) NM $50 \mu \mathrm{g} / \mathrm{ml}$, (C) NM $100 \mu \mathrm{g} / \mathrm{ml}$, (D) NM $250 \mu \mathrm{g} / \mathrm{ml}$, (E) NM $500 \mu \mathrm{g} / \mathrm{ml}$ and (F) NM $1000 \mu \mathrm{g} / \mathrm{ml}$.

Western blot analysis of Pgp and ECL detection. Cells were lysed with $1 \%$ Triton X-100 and $0.5 \%$ deoxycholate (in phosphate buffer $\mathrm{pH} 7.4), 1 \mathrm{mM}$ phenylmethylsulfonyl fluoride and centrifuged at $1,000 \mathrm{~g}$. The supernatant was collected and the total protein concentration was determined by a bicinchoninic acid protein assay (Pierce, Rockford, IL, USA). The cell membrane proteins $(10 \mu \mathrm{g} /$ lane) were separated by $10 \%$ SDS-PAGE and electroblotted overnight onto nitrocellulose filters. The filters were incubated sequentially with primary mouse monoclonal anti-Pgp clone F4 at 1:500 and 11RP-conjugated goat anti-mouse $\operatorname{IgC}$ at a 1:20,000 dilution. Proteins were visualized by the SuperSignal protein detection kit (enhanced chemiluminescence, ECL), and quantified by scanning densitometry.

Rh accumulation and efflux assays. Rh accumulation assay was performed in 24-well plates in MES-SA and MES-SA/DX5 cancer cells using fluorescence detection $(18,19)$. Cells were seeded onto 24-well flat-bottom plates and incubated in 5\% $\mathrm{CO}_{2}$ at $37^{\circ} \mathrm{C}$ for 3 days. Rh123 $(20 \mu \mathrm{M})$ was added to the cells in the absence or presence of NM at doses 100, 250, 500 and $1,000 \mu \mathrm{g} / \mathrm{ml}$ and incubated at $37^{\circ} \mathrm{C}$ in $5 \% \mathrm{CO}_{2}$ for $40 \mathrm{~min}$. The culture medium was removed and the cells were washed twice with cold PBS. The green fluorescence of Rh123 was measured at 485/20 $\mathrm{nm}$ excitation and 530/25 $\mathrm{nm}$ emission by florescence microplate reader (Millipore Cytofluor 2300, Billerica, MA, USA). Each plate included a blank control (no cells), a cell control (which contained cells without NM) and tested wells, which contained cells with NM. In the Rh efflux assay, $20 \mu \mathrm{M}$ Rh123 were added to the cells for $40 \mathrm{~min}$ and the culture medium was removed. The cells were incubated in fresh culture medium with or without $\mathrm{NM}$ at $37^{\circ} \mathrm{C}$ in $5 \%$ $\mathrm{CO}_{2}$ for an additional hour. Cellular residual $\mathrm{Rh} 123$ was measured by a fluorescence microplate reader (Millipore Cytofluor 2300) and images were captured by fluorescence microscopy. 

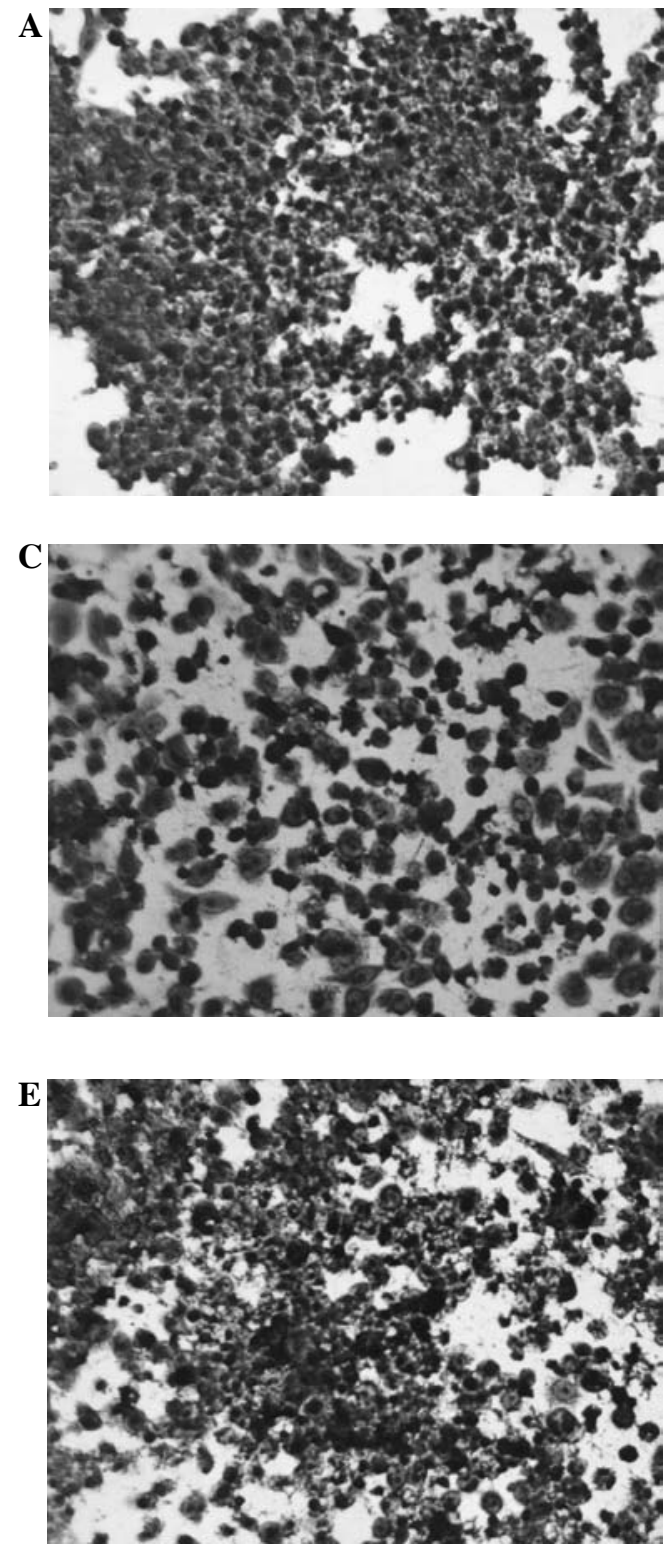
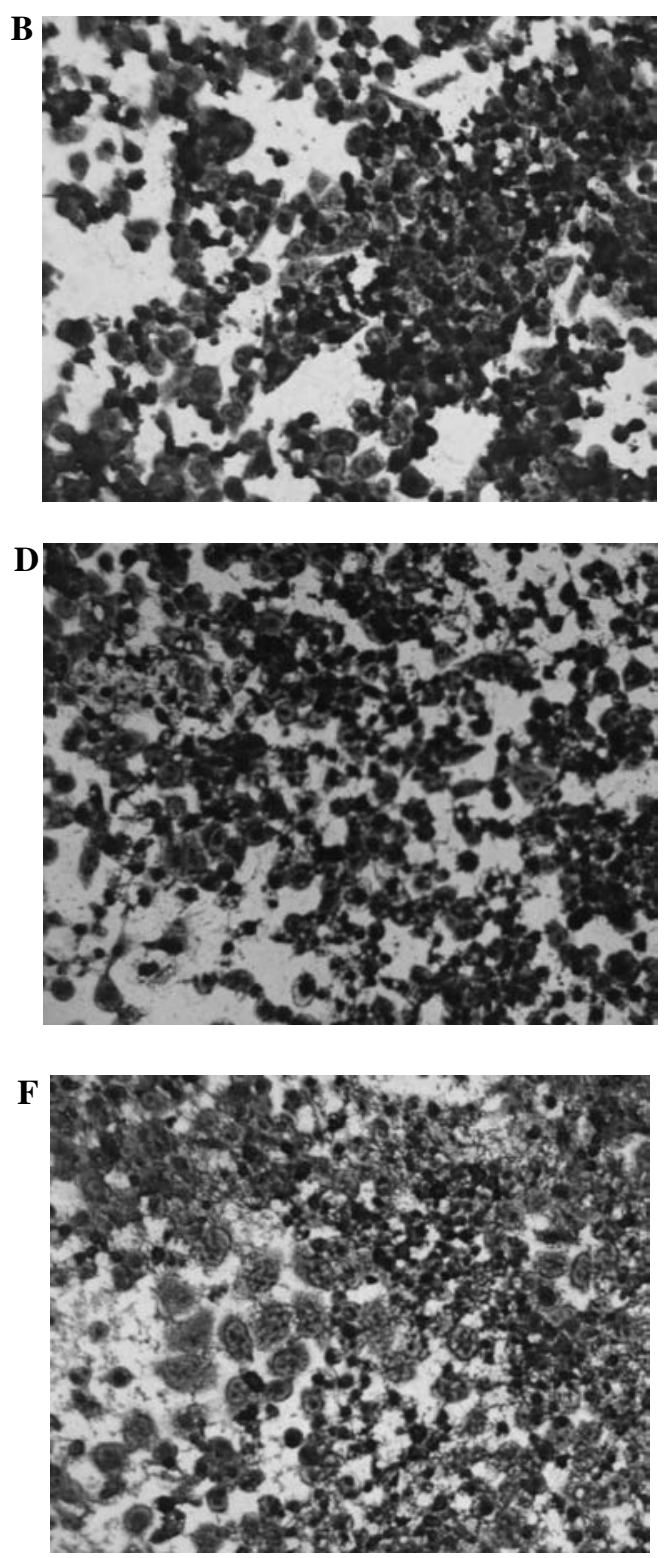

Figure 3. Effects of NM on morphology of MESA/Dx5 cells: H\&E staining. (A) Control, (B) NM $50 \mu \mathrm{g} / \mathrm{ml}$, (C) NM $100 \mu \mathrm{g} / \mathrm{ml}$, (D) NM $250 \mu \mathrm{g} / \mathrm{ml}$, (E) NM $500 \mu \mathrm{g} / \mathrm{ml}$ and (F) NM $1000 \mu \mathrm{g} / \mathrm{ml}$.

Statistical analysis. The results were expressed as the means \pm SD. Data were analyzed by independent sample t-test.

\section{Results}

Effects of NM on viability of MESA/DX 5 and MES-SA cells. MES-SA/Dx 5 cell viability was decreased with NM treatment by $21 \%$ at $50 \mu \mathrm{g} / \mathrm{ml}$ and by 36,40 and $48 \%$ at 250,500 and $1,000 \mu \mathrm{g} / \mathrm{ml}$, respectively (linear trend $\mathrm{R}^{2}, 0.8306$; Fig. 1). By contrast, NM treatment of the drug-sensitive cell line, MES-SA, demonstrated significantly higher cytotoxicity to cells, resulting in a $40 \%$ decrease in viability compared to the control at $50 \mu \mathrm{g} / \mathrm{ml}, 46 \%$ at $100 \mu \mathrm{g} / \mathrm{ml}, 65 \%$ at 500 and $72 \%$ at $1,000 \mu \mathrm{g} / \mathrm{ml}$ (linear trend $\mathrm{R}^{2}, 0.9271 ;$ Fig. 1). The difference in NM cytotoxicity between MES-SA and MES-SA/Dx 5 cells reached statistical significance. At NM $100 \mu \mathrm{g} / \mathrm{ml}$, the cell viability of MES-SA cells was $66.7 \%(\mathrm{P}=0.0005)$ of that of
MES-SA/Dx 5 cells, at NM $500 \mu \mathrm{g} / \mathrm{ml}, 58.3 \%(\mathrm{P}=0.001)$ and at $\mathrm{NM} 1,000 \mu \mathrm{g} / \mathrm{ml}, 53.8 \%(\mathrm{P}=0.001)$.

Effects of NM on morphology of MESA/DX 5 and MES-SA cells: $H \& E$ staining. The morphology of MES-SA (Fig. 2A-F) and MES-SA/Dx5 (Fig. 3A-F) cells was not affected at concentrations of $\leq 250 \mu \mathrm{g} / \mathrm{ml} \mathrm{NM}$. However, at 500 and $1,000 \mu \mathrm{g} / \mathrm{ml}$ NM both cell lines showed changes, such as apoptosis.

Effects of NM on MMP secretion in MESA/DX 5 and MES-SA cells: Gelatinase zymography. In the two cell lines, zymography demonstrated a band corresponding to MMP-2 in normal cells and to MMP-9 with PMA treatment. NM inhibited the secretion of both MMPs in a dose-dependent manner. Zymograms of normal and PMA (100 ng/ml)-treated MES-SA and MES-SA/Dx 5 cells are shown in Fig. 4. Densitometry analyses of PMA-treated cells are shown in Fig. 4C and F. 
A

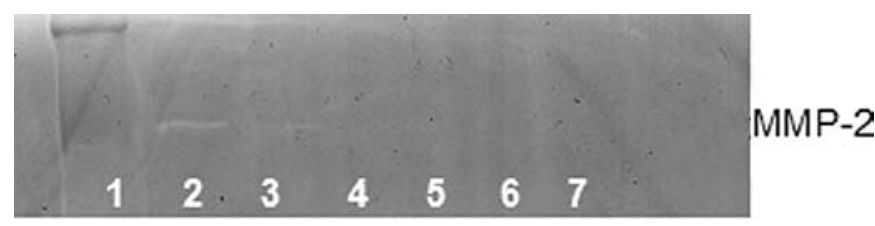

C

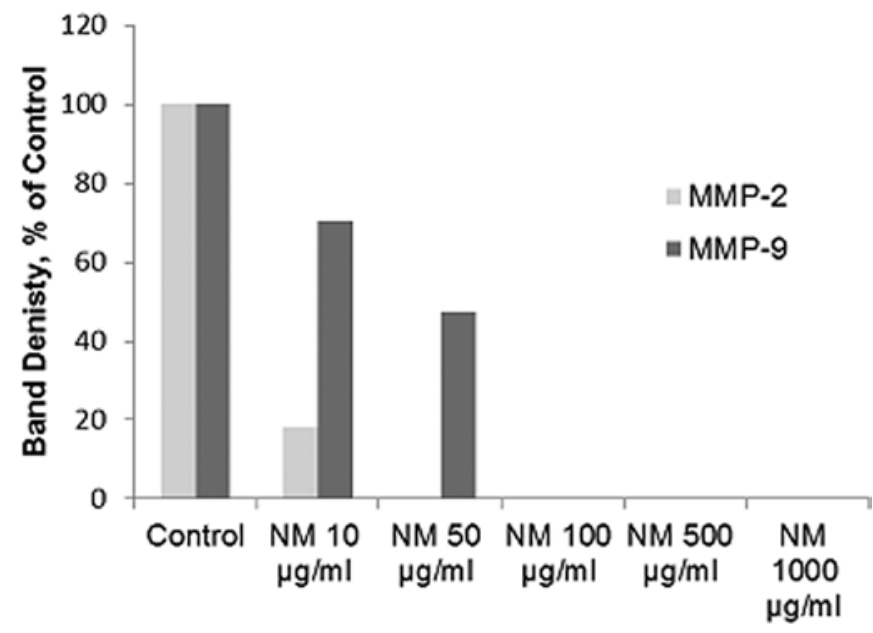

$\mathbf{E}$

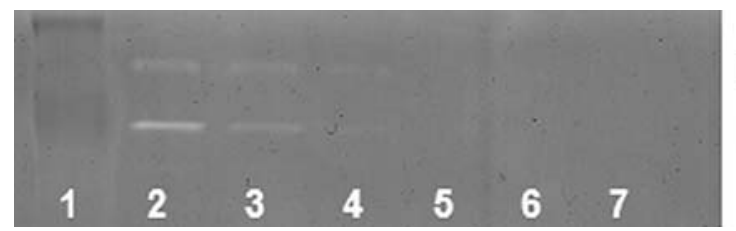

B

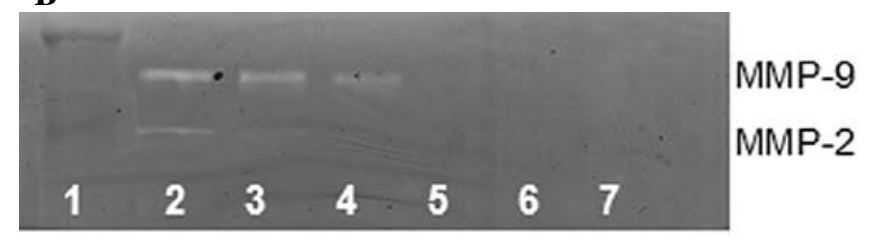

D

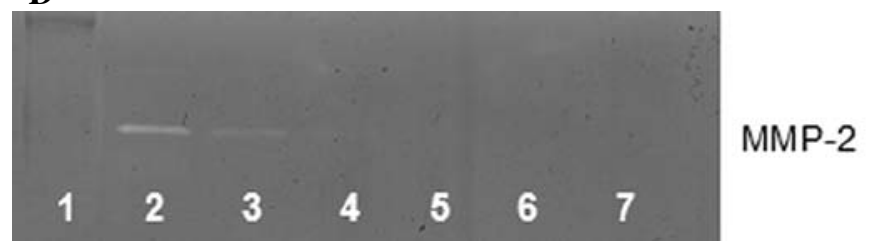

F

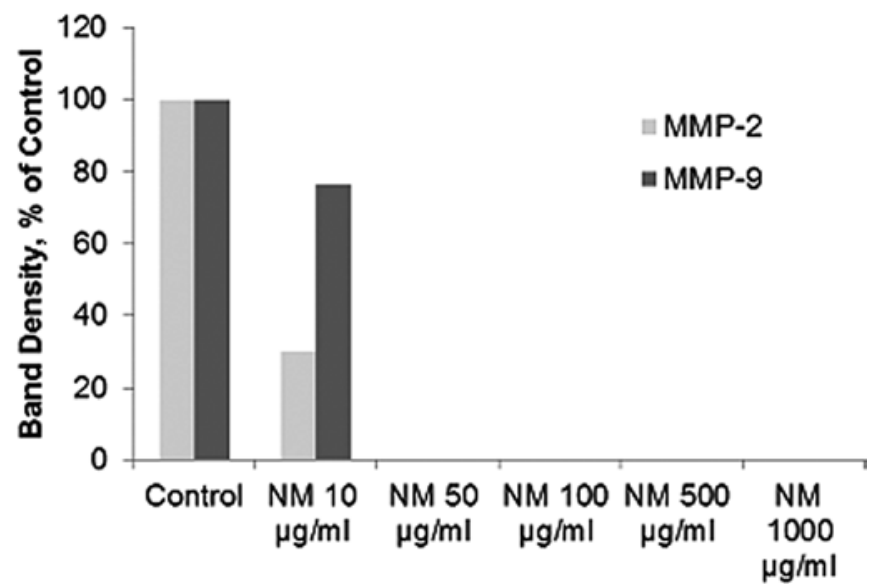

Figure 4. Effects of NM on MMP-2 and -9 secretion in MES-SA and MESA/Dx5 cells. Zymograms of (A) normal MES-SA and (B) PMA-treated MES-SA cells. 1, markers; 2, control; 3-7, NM 50, 100, 250, 500 and 1,000 $\mu \mathrm{g} / \mathrm{ml}$, respectively. (C) Densitometry of PMA-treated MES-SA cells. (D) Zymograms of normal MES-SA/Dx5 and (E) PMA-treated MES-SA/Dx5 cells. 1, markers; 2, control; 3-7, NM 50, 100, 250, 500 and 1,000 $\mu$ g/ml, respectively. (F) Densitometry of PMA-treated MES-SA/Dx5 cells.

Effects of NM on MESA/DX 5 and MES-SA cell Matrigel invasion. NM inhibited MES-SA and MES-SA/Dx5 cell invasion through Matrigel in a dose-dependent manner with $100 \%$ block of MES-SA cell Matrigel invasion at $250 \mu \mathrm{g} / \mathrm{ml} \mathrm{NM}$ and MES-SA/Dx 5 cell invasion at $50 \mu \mathrm{g} / \mathrm{ml} \mathrm{NM}$, as shown in Fig. 5.

Effects of NM on MESA/DX 5 and MES-SA cell Pgp expression. As shown by Western blot analysis, the MES-SA/Dx5 cell line exhibited dose-dependent Pgp expression, while MES-SA did not exhibit Pgp (Fig. 6A). The NM treatment resulted in a dose-dependent decrease of Pgp expression in the MES-SA/Dx 5 cell line, as shown by Western blot analysis (Fig. 6B) and by immunodetection (Fig. 8), whereas MES-SA did not exhibit Pgp by immunostaining (Fig. 7).

Effects of NM on accumulation and efflux of Pgp substrate Rh123. NM enhanced the accumulation and efflux of the Pgp substrate, Rh123, in the MES-SA/Dx5 uterine sarcoma, but not in the drug-sensitive MES-SA cell line. Figs. 9 and 11 show graphical representations of NM effects on Pgp accumulation and efflux, respectively, in both cell lines. Photoluminescent images of NM effects on MES-SA and MES-SA/Dx5 Rh123 uptake are shown in Fig. 10.

Rh123 uptake in drug-insensitive MES-SA/Dx5 cells demonstrated increased levels with NM treatment (linear trend $\mathrm{R}^{2}, 0.2438$ ), with $180 \%$ of control level at $100 \mu \mathrm{g} / \mathrm{ml}$ and $247 \%$ at $1,000 \mu \mathrm{g} / \mathrm{ml}$. By contrast, no significant change in Rh123 was detected in the drug-sensitive MES-SA cells exposed to various concentrations of NM (linear trend $\mathrm{R}^{2}, 0.5774$ ). The differences between MES-SA/Dx5 and MES-SA Rh123 levels reached statistical significance. At NM $100 \mu \mathrm{g} / \mathrm{ml}$, MES-SA Rh123 levels were $57.2 \%(\mathrm{P}=0.009)$ those of MES-SA/Dx5 cells and at NM 1,000 $\mu \mathrm{g} / \mathrm{ml}, 38.1 \%(\mathrm{P}=0.003)$.

In the drug-sensitive MES-SA cells, Rh123 residue demonstrated no significant change with the addition of increasing concentrations of NM (linear trend $\mathrm{R}^{2}, 0.5934$ ). Conversely, in the MES-SA/Dx5 cells, RH123 residue increased with NM concentration (linear trend $\mathrm{R}^{2}, 0.1699$ ).

\section{Discussion}

In the present study, the drug-sensitive human sarcoma cancer cell line was more invasive than the drug-insensitive counter- 

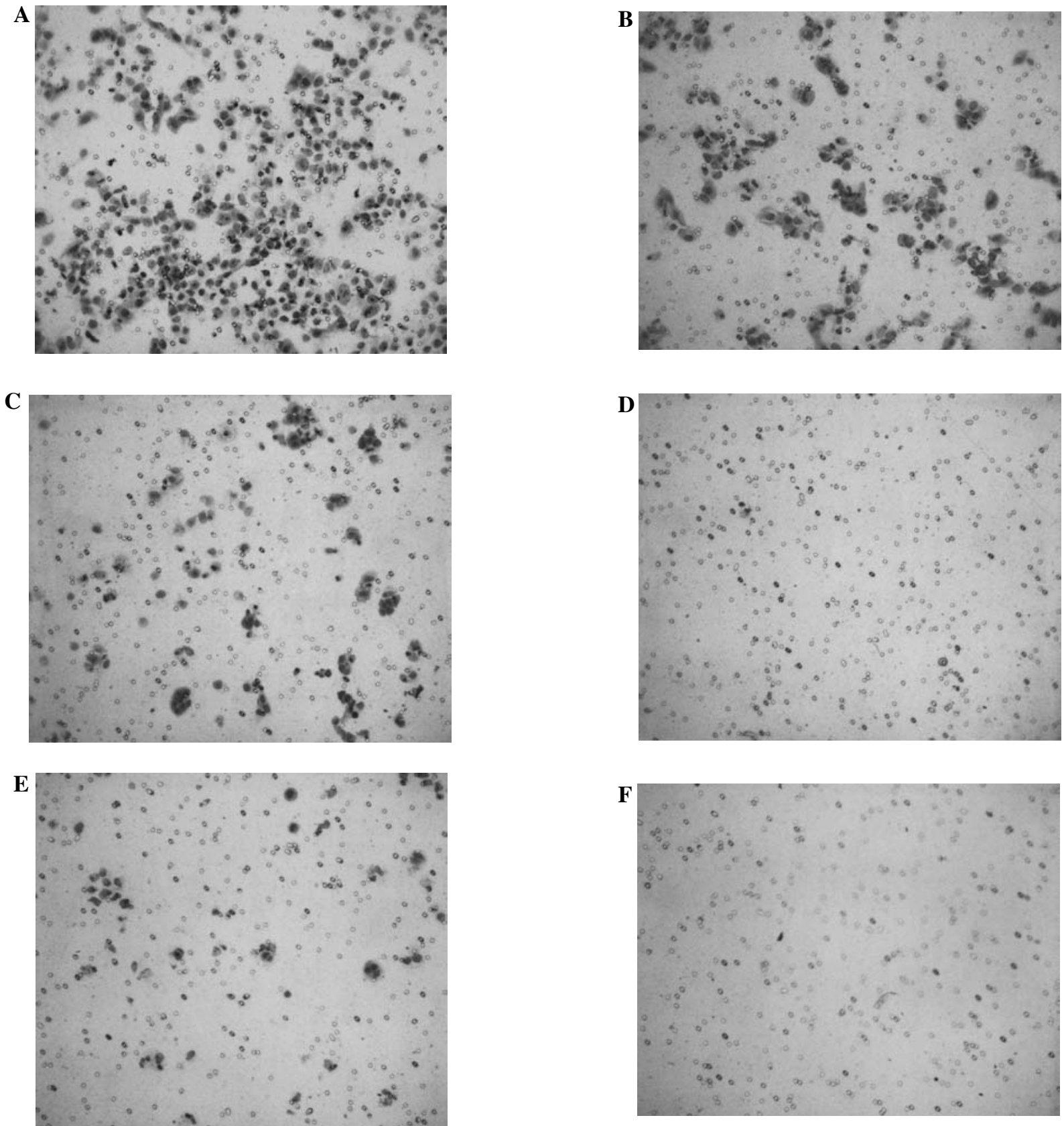

Figure 5. Effects of NM on MESA/Dx5 and MES-SA cell Matrigel invasion. (A) MES-SA control, (B) MES-SA NM $50 \mu \mathrm{g} / \mathrm{ml}$, (C) MES-SA NM $100 \mu \mathrm{g} / \mathrm{ml}$, (D) MES-SA NM $250 \mu \mathrm{g} / \mathrm{ml}$, (E) MES-SA/Dx5 control and (F) MES-SA/Dx5 NM $50 \mu \mathrm{g} / \mathrm{ml}$.
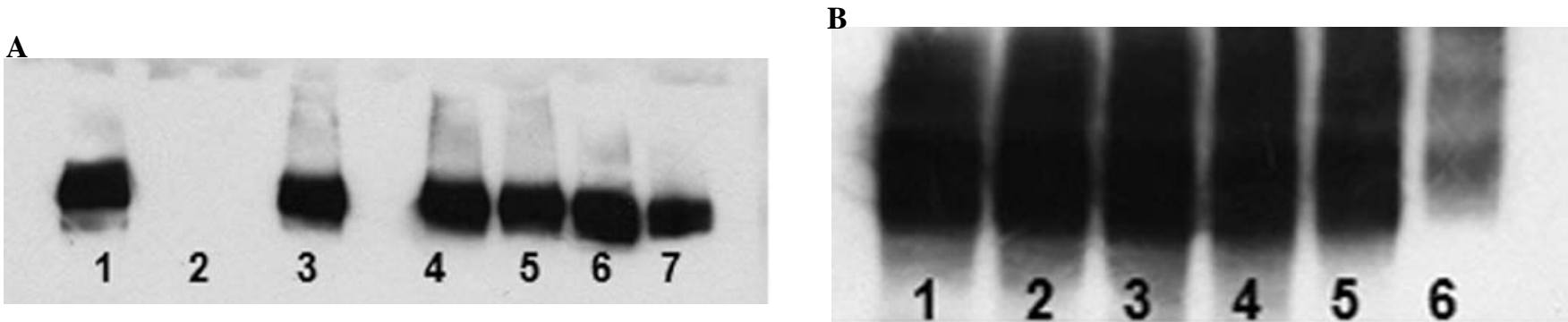

Figure 6. (A) Pgp expression of MES-SA and MES-SA/Dx5 cells: Western blot analysis. (B) Effects of NM on Pgp expression of MES-SA/Dx5 cells: Western blot analysis. 

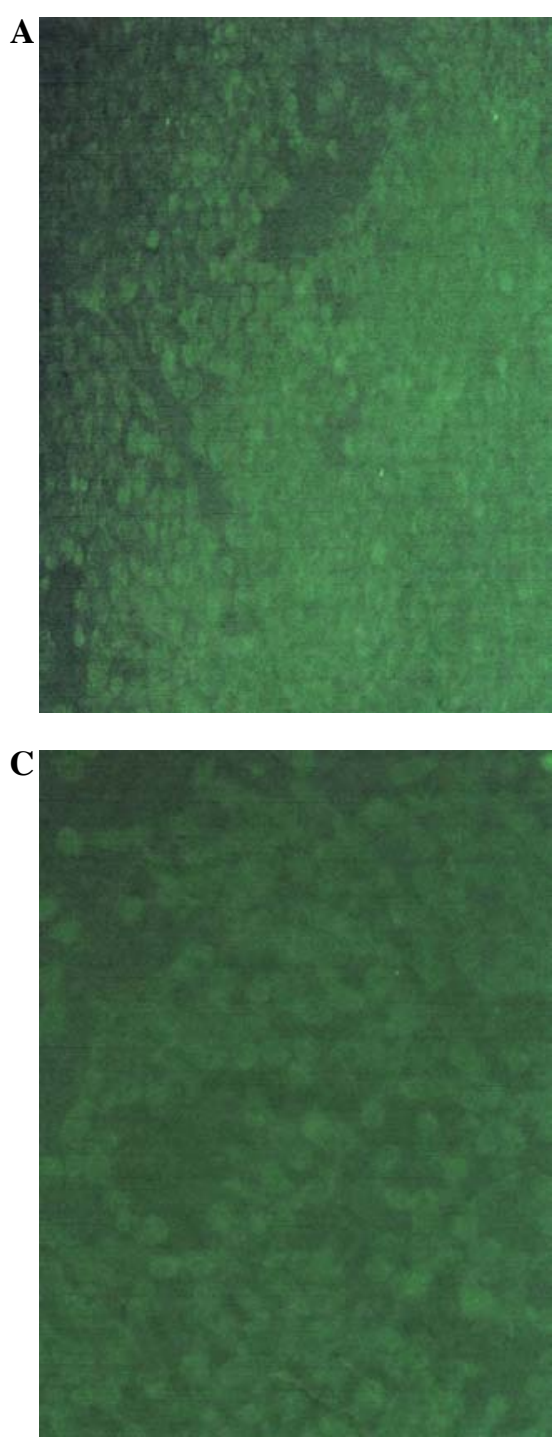

Figure 7. Effects of NM on Pgp expression in MES-SA cells: Immunofluorescence. (A) Control, (B) NM $100 \mu \mathrm{g} / \mathrm{ml}$ and (C) NM $250 \mu \mathrm{g} / \mathrm{ml}$.

part and NM modulated cancer cell MMP activity and invasion of both cell lines, as well as Pgp in MES-SA/Dx5 cells. As regards the Matrigel invasion, drug-insensitive MES-SA/Dx5 cells were less invasive than the drug-sensitive MES-SA cells. At control conditions (no NM present), a substantially larger number of MES-SA cells invaded the Matrigel barrier compared to the MES-SA/Dx5 cells. NM completely blocked Matrigel invasion in drug-insensitive MES-SA/Dx5 cells at a lower concentration compared to the drug-sensitive MES-SA cells. Liang et al reported that some tumor cells selected for resistance to drugs are more invasive/metastatic than their non-resistant parental cells, while other tumour cells have not been shown to be correlated with invasion or metastasis (20). Cancer cell invasion has been shown to be correlated with MMP activity, as reported in a previous study (21).

Pgp activity in the cell accumulation assay is measured by the intracellular concentration of the Pgp substrate, Rh123. Thus, inhibition of Pgp activity results in increased intracellular Rh123 concentrations reflected in higher fluorescent signals compared to control cells. Rh123 uptake in drug-

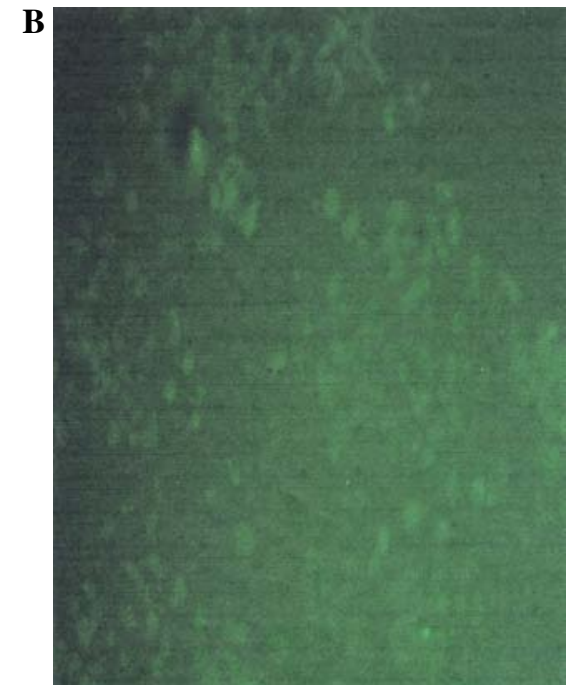

insensitive MES-SA/Dx5 cells demonstrated increased levels with NM concentration. However, no significant change in Rh123 was detected in drug-sensitive MES-SA cells exposed to various concentrations of NM. Drug-sensitive MES-SA cells do not have Pgp, thus Rh123 would not be affected by NM treatment. In MES-SA/Dx5 cells, uptake was increased with NM as NM inhibits Pgp activity. By contrast, inducers of Pgp activity cause enhanced efflux of Rh123, leaving intracellular concentrations below control values.

The residue assay was conducted by pre-loading cells with Rh123 and then treating with NM. The residual dye in the cell is inversely related to the pumping action in the cell. In drug-sensitive MES-SA cells, Rh123 residue demonstrated no significant change with the addition of increasing concentrations of NM (linear trend $\mathrm{R}^{2}, 0.5934$ ). Conversely, in the MES-SA/Dx 5 cells, Rh123 residue increased with NM concentration. Therefore, the increased residual dye level in MES-SA/Dx 5 cells suggests the inhibition of MDR-1 activity. NM was significantly more cytotoxic to drug-insensitive MES-SA cells than to MES-SA/Dx5 cells, indicating that the overexpression of Pgp in MES-SA/Dx5 cells may play a role in protecting MES-SA/Dx 5 cells against NM by transporting NM out of the cell.

Drug resistance to chemotherapeutic agents accounts for treatment failure in more than $90 \%$ of patients with metastatic cancer (22). A major mechanism of this resistance is the enhanced efflux of chemotherapeutic agents due to overexpression of Pgp. Studies have shown that compounds in plants, including vegetables and fruits, not only have anticancer activities but may also modulate Pgp activity, rendering them more effective in treating cancers deemed resistant due to production of Pgp. For example, polyphenols have been reported to exhibit anticancer activity and to modulate Pgp activity in various cancer cell lines (23-26).

The NM is a mixture of nutrients that act on critical physiological targets in cancer progression and metastasis. The anticancer effects of the individual constituents of the NM have been reported in both clinical and experimental studies (27-29). Green tea (23), vitamin C (30) and selenium (31) have been shown to reverse multidrug resistance. Adequate supplies 

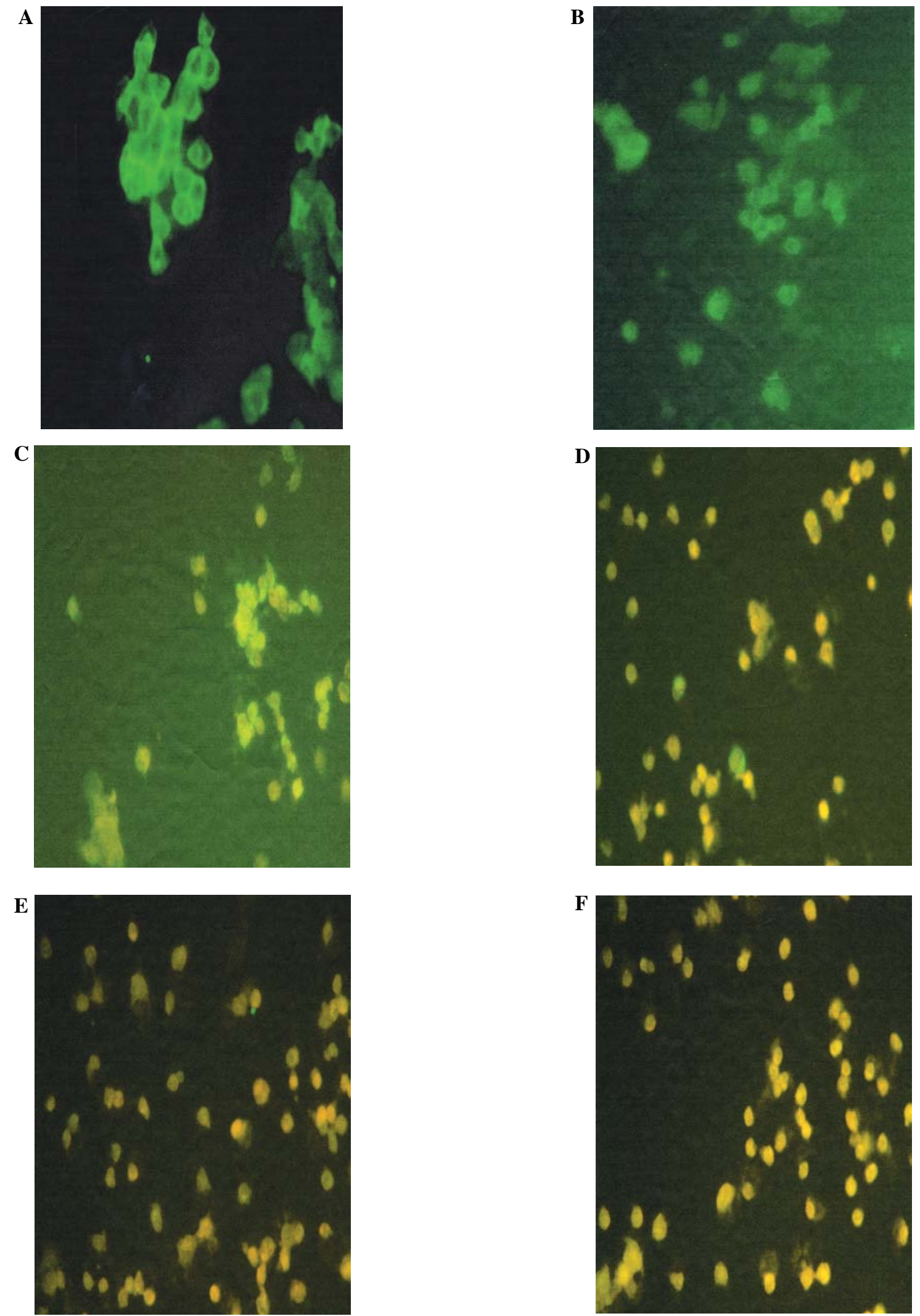

Figure 8. Effects of NM on Pgp expression in MES-SA/Dx 5 cells: Immunofluorescence. (A) Control, (B) NM $50 \mu \mathrm{g} / \mathrm{ml}$, (C) NM $100 \mu \mathrm{g} / \mathrm{ml}$, (D) NM $250 \mu \mathrm{g} / \mathrm{ml}$, (E) NM $500 \mu \mathrm{g} / \mathrm{ml}$ and (F) NM $1,000 \mu \mathrm{g} / \mathrm{ml}$.

of ascorbic acid and the amino acids, lysine and proline, are essential for optimal extracellular matrix (ECM) formation and structure as these nutrients insure proper synthesis and hydroxylation of collagen fibers. Manganese and copper are also essential for collagen formation. Lysine contributes to ECM stability as a natural inhibitor of plasmin-induced proteolysis $(32,33)$. Green tea extract has been shown to control cancer cell growth, metastasis, angiogenesis, as well as other 


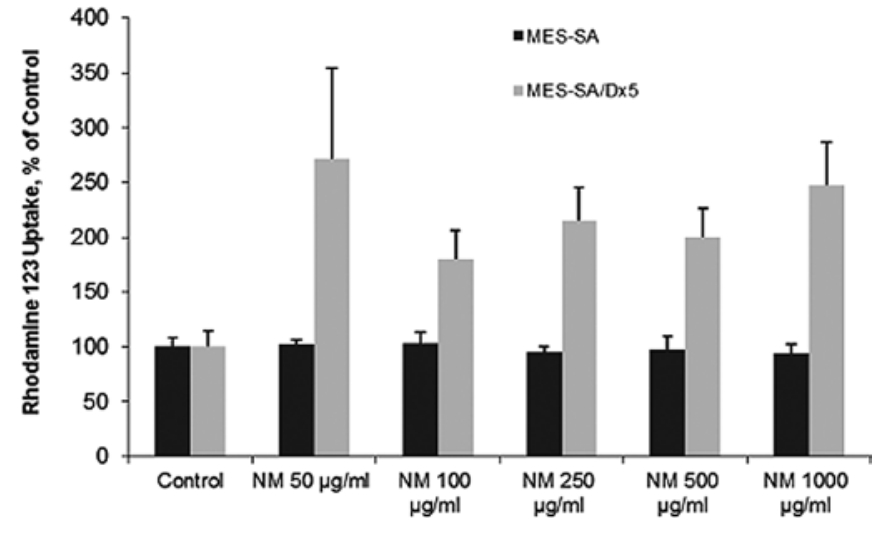

Figure 9. Effects of NM on MES-SA and MES-SA/Dx5 Rh123 uptake.

aspects of cancer progression (34-40). N-acetyl cysteine and selenium have been observed to inhibit MMP-9 and invasive activities of tumor cells, as well as migration of endothelial cells through ECM (41-43). Ascorbic acid is known to exert cytotoxic and antimetastatic actions on malignant cell lines
(44-48). Arginine is a precursor of nitric oxide (NO); any deficiency of arginine can limit the production of NO, which has been shown to predominantly act as an inducer of apoptosis, as in breast cancer cells (49).

Furthermore, in contrast to the toxic side-effects of current chemotherapy, the NM is a safe therapeutic agent. In a previous in vivo study addressing safety issues, we found that gavaging adult female ODS rats (weighing 250-300 gm) with the NM (at 30,90 or $150 \mathrm{mg}$ per day for seven days), had neither adverse effects on vital organs (heart, liver and kidney), nor on the associated functional serum enzymes, indicating that this mixture is safe to use even at these high doses, which far exceed the normal equivalent dosage of the nutrient (50).

In conclusion, the drug-resistant cancer cell line was more responsive to NM compared to the drug-sensitive cell line, which suggests therapeutic potential for all cancers. As NM modulates Pgp, it has significant potential in treating resistant cancers that secrete Pgp. Therefore, in contrast to chemotherapeutic drugs that not only have potent toxic effects but are ineffective in treating drug-resistant cancers, the NM not only has low toxicity but has also shown potential efficacy in the treatment of drug-resistant cancer by the modulation of

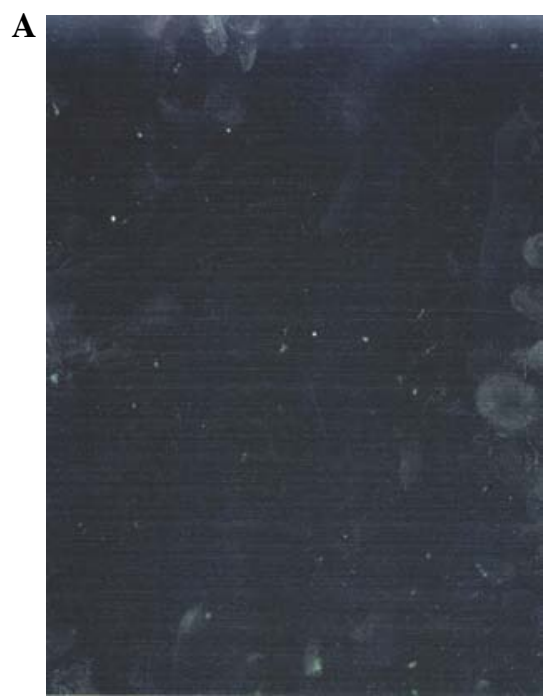

C

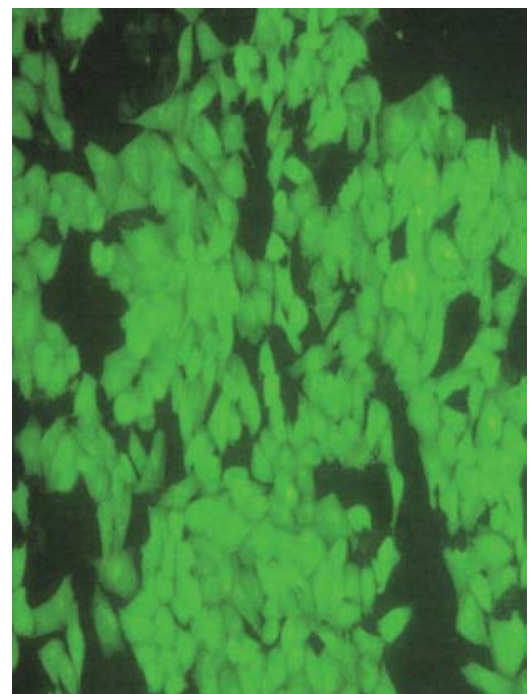

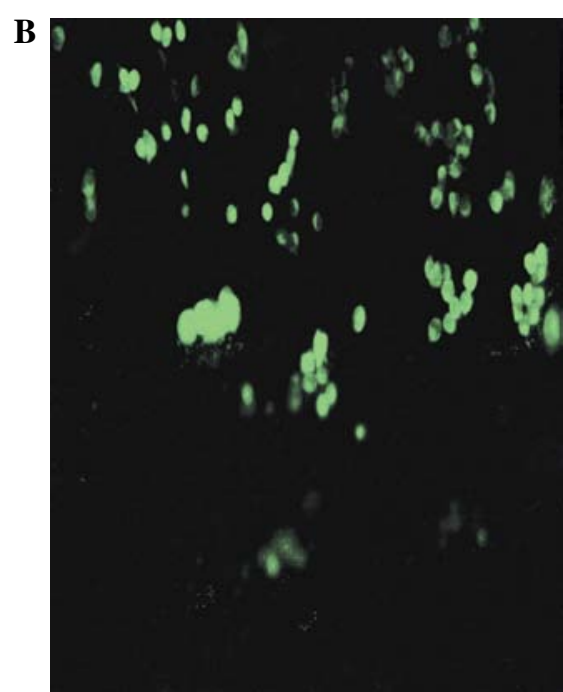

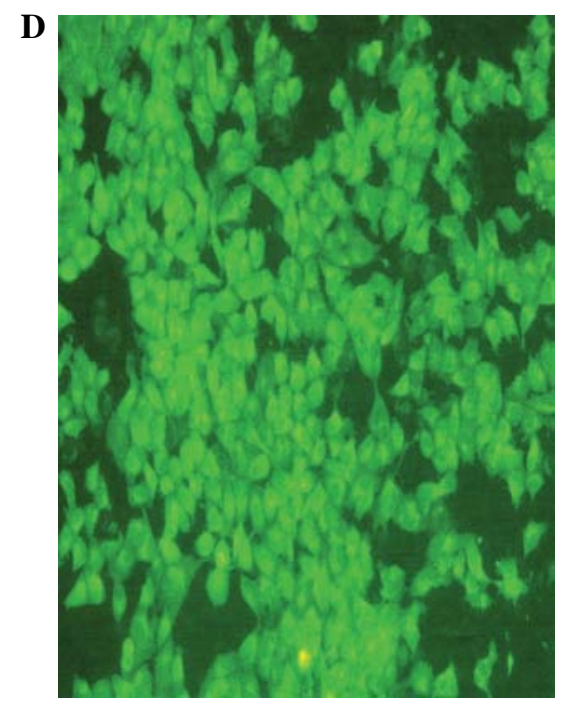

Figure 10. Effects of NM on MES-SA and MES-SA/Dx5 Rh123 uptake. (A) MES-SA/Dx5 control, (B) MES-SA/Dx5 NM $250 \mu \mathrm{g} / \mathrm{ml}$. (C) MES-SA control and (D) MES-SA NM $250 \mu \mathrm{g} / \mathrm{ml}$. 


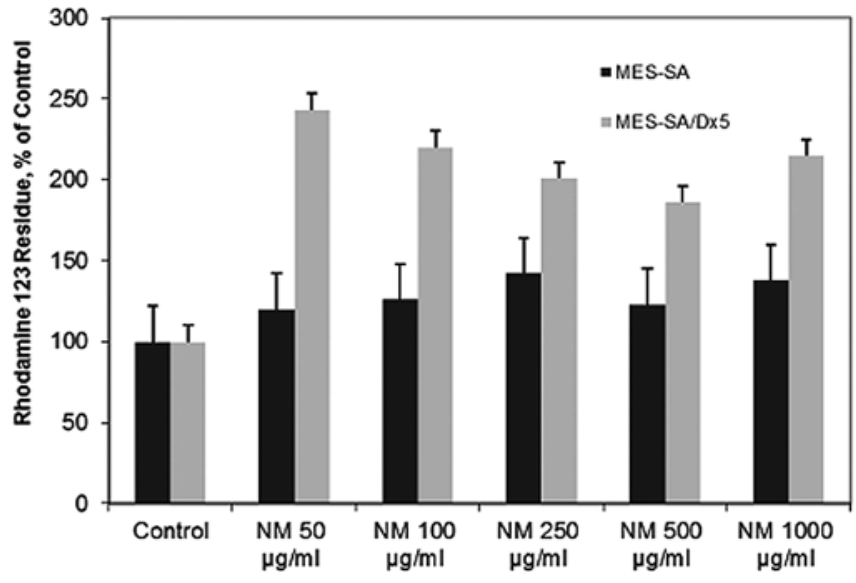

Figure 11. Effects of NM on MES-SA and MES-SA/Dx5 Rh123 residue.

Pgp, rendering increased cell concentration of NM and, thus, increasing anticancer activity.

\section{Acknowledgements}

This study was funded by the Dr Rath Health Foundation (Plantation, Florida, USA), a non-profit organization.

\section{References}

1. Choi $\mathrm{CH}$ : $\mathrm{ABC}$ transporters as multidrug resistance mechanisms and the development of chemosenstizers for their reversal. Cancer Cell Int 5: 30-43, 2005

2. Liscovitch $M$ and Lavie Y: Cancer multidrug resistance: a review of recent drug discovery research. IDrugs 5: 349-355, 2002.

3. Ozben T: Mechanisms and strategies to overcome multiple drug resistance in cancer. FEBS Let 580: 2903-2909, 2006.

4. Szakacs G, Patterson JK, Ludwig JA, Booth-Genthe C and Gottesman MM: Targeting multidrug resistance in cancer. Nat Rev Drug Discov 5: 219-234, 2006.

5. Hyde SC, Emsley P, Hartshorn MJ, Mimmacck MM, Gileadi U, Pearce SR, Gallagher MP, Gill DR, Hubbard RE and Higgins SF: Structural model of ATP-binding proteins associated with cystic fibrosis, multidrug resistance and bacterial transport. Nature 346: 362-365, 1990.

6. Leonard GD, Fojo T and Bates SE: The role of ABC transporters in clinical practice. Oncologist 8: 411-424, 2003.

7. Rosenberg MF, Kamis AB, Callaghan R, Higgins $\mathrm{CF}$ and Ford RC: Three-dimensional structures of the mammalian multidrug resistance P-glycoprotein demonstrate major conformational changes in the transmembrane domains upon nucleotide binding. J Biol Chem 278: 8294-8299, 2003.

8. Endicott JA and Ling V: The biochemistry of P-glycoprotein mediated multidrug resistance. Annu Rev Biochem 58: 37-71, 1989.

9. Ueda K, Cardarelli G, Gottsman MM and Pastan I: Expression of a full length cDNA for the human 'MDR1' gene confers resistance to colchicines, doxorubicin and vinblastin. Proc Natl Acad Sci USA 84: 3004-3008, 1987.

10. Robert J and Jarry C: Multidrug resistance reversal agents. J Med Chem 46: 4805-4817, 2003.

11. Thomas $\mathrm{H}$ and Coley JM: Overcoming multidrug resistance in cancer: an update on the clinical strategy of inhibiting P-glycoprotein. Cancer Control 10: 159-165, 2003.

12. Quesada AR, Barbacid MM, Mira E, Aracil M and Marquez G: Chemosensitization and drug accumulation assay: complementary methods for the screening of multidrug resistance reversal agents. Cancer Lett 99: 109-114, 1996.

13. Sarver JG, Klis WA, Byers JP and Erhardt PW: Microplate screening of the differential effects of test agents on Hoechst 33342 , rhodamine 123 , and rhodamine $6 \mathrm{G}$ accumulation in breast cancer cells that overexpress P-glycoprotein. J Biomol Screen 7: 29-34, 2002.
14. Perloff MD, von Moltke LL, Marchand JE and Greenblatt DJ: Ritonavir induces P-glycoprotein expression, multidrug resistance-associated protein (MRP1) expression, and drug transporter-mediated activity in a human intestinal cell line. J Pharm Sci 90: 1829-1837, 2001.

15. Lee JS, Paull K, Alvarez M, Hose C, Monks A, Grever M, Fojo AT and Bates SE: Rhodamine efflux patterns predict P-glycoprotein in the National Cancer Institute drug screen. Mol Pharmacol 46: 627-638, 1994

16. Niedzwiecki A, Roomi MW, Kalinovsky $\mathrm{T}$ and Rath $\mathrm{M}$ : Micronutrient synergy - a new tool in effectsive control of metastasis and other key mechanisms of cancer. Cancer Metastasis Rev 29: 529-542, 2010.

17. Wesolowsla O, Paprocka M, Kozlak J, Motohashi N, Dus D and Michalak K: Human sarcoma cell lines MES-SA and MES-SA/ Dx5 as a model for multidrug resistance modulators screening. Anticancer Res 25: 383-389, 2005.

18. Choi SU, Lee CO, Kim KH, Choi EJ, Park SH, Shin HS, Yoo SE, Jung NP and Lee BH: Reversal of multidrug resistance by novel verapamil analogs in cancer cells. Anticancer Drugs 9: 157-165, 1998.

19. Koo JS, Choi WC, Rhee YH, Lee HJ, Lee EO, Ahn KS, Bae HS, Ahn KS, Kang JM, Choi SU, Kim MO, Lu J and Kim SH: Quinoline derivative KB3-1 potentiates paclitaxel induced cytotoxicity and cycle arrest via multidrug resistance reversal in MES-SA/Dx5 cancer cells. Life Sci 83: 700-708, 2008.

20. Liang Y, McDonnell S and Clynes M: Exploring the relationship between cancer invasion/metastasis and drug resistance. Curr Cancer Drug Targets 2: 257-277, 2002.

21. Roomi MW, Monterrey JC, Kalinovsky T, Rath $\mathbf{M}$ and Niedzwiecki A: Inhibition of invasion and MMPs by a nutrient mixture in human cancer cell lines: a correlation study. Exp Oncol 32: 243-248, 2010.

22. Longley DB and Johnston PG: Molecular mechanisms of drug resistance. J Pathol 205: 275-292, 2005.

23. Jodoin J, Demeule M and Béliveau R: Inhibition of the multidrug resistance P-glycoprotein activity by green tea polyphenols. Biochim Biophys Acta 1542: 573-159, 2002.

24. Anuchapreeda S, Leechanachai P, Smith MM, Ambudkar SV and Limtrakul P: Modulation of P-glycoprotein expression and function by curcumin in multidrug-resistant human KB cells. Biochem Pharmacol 64: 573-582, 2002.

25. Limtrakul P, Anuchapreeda S and Buddhasukh D: Modulation of human multidrug-resistance MDR-1 gene by natural curcuminoids. BMC Cancer 4: 13, 2004.

26. Go EJ, Chung SY, Kim NH and Lee HJ: Modulation of p-glycoprotein activity by flavonoids in human uterine sarcoma cells. J Kor Pharm Sci 33: 305-310, 2003.

27. Roomi MW, Roomi NW, Ivanov V, Kalinovsky T, Niedzwiecki A and Rath M: Inhibition of pulmonary metastasis of melanoma B16FO cells in C57BL/6 mice by a nutrient mixture consisting of ascorbic acid, lysine, proline, arginine, and green tea extract. Exp Lung Res 32: 517-530, 2006.

28. Roomi MW, Monterrey JC, Kalinovsky T, Rath M and Niedzwiecki A: Comparative effects of EGCG, green tea and a nutrient mixture on the patterns of MMP-2 and MMP-9 expression in cancer cell lines. Oncol Rep 24: 747-757, 2010.

29. Roomi MW, Roomi NW, Kalinovsky T, Niedzwiecki A and Rath M: In vivo and in vitro effects of a nutrient mixture on human hepatocarcinoma cell line SK-Hep-1. Exp Oncol 32: 84-91, 2010.

30. El-Masry EM and Abou-Donia MB: Reversal of P-glycoprotein expressed in Escherichia coli leaky mutant by ascorbic acid. Life Sci 73: 981-991, 2003.

31. Shallom J, Juvekar A and Chitnis M: Selenium (Se) cytotoxicity in drug sensitive and drug-resistant murine tumour. Cancer Biother 10: 243-248, 1995.

32. Rath M and Pauling L: Plasmin-induced proteolysis and the role of apoprotein(a), lysine and synthetic analogs. J Orthomolecular Med 7: 17-23, 1992.

33. Sun Z, Chen YH, Wang P,Zhang J, Gurewich V, Zhang P and Liu JN: The blockage of high-affinity lysine binding sites of plasminogen by EACA significantly inhibits prourokinase-induced plasminogen activation. Biochem Biophys Acta 1596: 182-192, 2002.

34. Kemberling JK, Hampton JA, Keck RW, Gomez MA and Selman SH: Inhibition of bladder tumor growth by the green tea derivative epigallocatechin-3-gallate. J Urol 170: 773-776, 2003.

35. Sato D and Matsushima M: Preventive effects of urinary bladder tumors induced by N-butyl-N-(4-hydroxybutyl)-nitrosamine in rat by green tea leaves. Int J Urol 10: 160-166, 2003. 
36. Valcic S, Timmermann BN, Alberts DS, Wachter GA Krutzsch M, Wymer J and Guillen JM: Inhibitory effects of six green tea catechins and caffeine on the growth of four selected human tumor cell lines. Anticancer Drugs 7: 461-468, 1996.

37. Mukhtar $\mathrm{H}$ and Ahmed N: Tea polyphenols: prevention of cancer and optimizing health. Am J Clin Nutr 71: 1698s-1702s, 2000.

38. Yang GY, Liao J, Kim K, Yurtow EJ and Yang CS: Inhibition of growth and induction of apoptosis in human cancer cell lines by tea polyphenols. Carcinogenesis 19: 611-616, 1998.

39. Taniguchi S, Fujiki H, Kobayashi H, Go H, Miyado K, Sadano H and Shimikawa R: Effects of (-) epigallocatechin gallate, the main constituent of green tea, on lung metastasis with mouse B16 melanoma cell lines. Cancer Lett 65: 51-54, 1992.

40. Hara Y: Green tea: Health Benefits and Applications. Marcel Dekker, New York, 2001.

41. Kawakami S, Kageyama Y, Fujii Y, Kihara K and Oshima H: Inhibitory effects of N-acetyl cysteine on invasion and MMP 9 production of T24 human bladder cancer cells. Anticancer Res 21: 213-219, 2001

42. Morini M, Cai T, Aluigi MG, Noonan DM, Masiello L, De Floro S, D'Agostinin F, Albini A and Fassima G: The role of the thiol $\mathrm{N}$-acetyl cysteine in the prevention of tumor invasion and angiogenesis. Int J Biol Markers 14: 268-271, 1999.

43. Yoon SO, Kim MM and Chung AS: Inhibitory effects of selenite on invasion of HT 1080 tumor cells. J Biol Chem 276: 20085-20092, 2001.
44. Naidu KA, Karl RC and Coppola D: Antiproliferative and proapoptotic effects of ascorbyl stearate in human pancreatic cancer cells: association with decreased expression of insulinlike growth factor 1 receptor. Dig Dis Sci 48: 230-237, 2003.

45. Anthony HM and Schorah CJ: Severe hypovitaminosis C in lungcancer patients: The utilization of vitamin $\mathrm{C}$ in surgical repair and lymphocyte-related host resistance. Br J Cancer 46: 354-367, 1982.

46. Maramag C, Menon M, Balaji KC, Reddy PG and Laxmanan S: Effects of vitamin $C$ on prostate cancer cells in vitro: effects on cell number, viability and DNA synthesis. Prostate 32: 188-195, 1997.

47. Koh WS, Lee SJ, Lee H, Park C, Park MH, Kim WS, Yoon SS, Park K, Hong SI, Chung MH and Park CH: Differential effects and transport kinetics of ascorbate derivatives in leukemic cell lines. Anticancer Res 8: 2487-2493, 1998.

48. Chen Q, Espey MG, Krishna MC, Mitchell JB, Corpe CP, Buettner GR, Shacter E and Levine M: Pharmacologic ascorbic acid concentrations selectively kill cancer cells: Action as a pro-drug to deliver hydrogen peroxide to tissues. Proc Natl Acad Sci USA 102: 13604-13609, 2005.

49. Cooke JP and Dzau VJ: Nitric oxide synthase: Role in the genesis of vascular disease. Annu Rev Med 48: 489-509, 1997.

50. Roomi MW, Ivanov V, Netke SP, Niedzwiecki A and Rath M: Serum markers of the liver, heart, and kidney and lipid profile and histopathology in ODS rats treated with nutrient synergy. J Am Coll Nutr 22: 477, Abst 86, 2003. 